\title{
Addressing Islamophobia Creatively in the Classroom
}

\author{
Michelle Savard \\ PhD Student \\ Department of Education \\ Concordia University \\ savar_95@education.concordia.ca
}

\begin{abstract}
This paper explores Islamophobia and how it manifests in the form of hate speech and hate crimes in both the United States and Canada. It examines how "othering" those from the Middle East and those who practice Islam has become normalized by journalists and government leaders to the extent that basic human rights are being restricted by this practice. The paper argues that the carefully engineered 'war on terror' is a government construction to justify the massacre of over one million Afghans, Iraqis and Pakistanis. Given the growing racism directed at all those from the Arab world, this paper puts forward suggestions on how Islamophobia can be deconstructed in the classroom using critical peace education and higher order learning. The paper concludes by suggesting some pedagogical approaches to enhance critical media skills and to encourage students to stand up against this pervasive racism.
\end{abstract}

\section{Introduction}

"I met Hakim at Bristol International Airport. We started to speak about the life of Muslims in Europe, and he emphasised 'After the 11 th of September, for many Muslims the life has not radically changed. It has only become worse"" (Marranci, 2004, p. 111).

On the second anniversary of $9 / 11$, the then Secretary of Defense Donald Rumsfeld, described 9/11 as a "blessing in disguise to give permission to the United States to do whatever they wanted to do in the Middle East" (Elver, 2012, p. 155). That blessing included laying the foundation for President Bush to connect Iraq with 9/11. According to Gershkoff \& Kushner, (2005), there was not widespread debate about the war. However, there was significant opposition to the war on social media. Despite the millions of Tweets, Facebook postings and blogs that appeared in protest of the US going to war in Iraq, President Bush simply acknowledged opposing opinions but did not respond (Dean, 2008). "By creating a cultural construction, the stereotype of a terrorist, as 'the other', leaders have been able to use extreme methods against terrorism, whether international or national, providing a space where human rights are restricted...(Evans, 2012, p. 71). Why did any Americans support the war in Iraq knowing it would result in so many lost lives? Primarily, it was because of the way the war was framed by the media. Gore Vidal who has been named as the conscience of America believes the war on terrorism is “...like a war against dandruff. There's no such thing as a war against 
terrorism. It's idiotic. These are slogans. These are lies. It's advertising, which is the only art form we ever invented and developed"(cited by Barsamian, 2006). Yet the "war on terror" has directly or indirectly, killed approximately one million people in Iraq, 220,000 in Afghanistan and 80,000 in Pakistan which is 1.3 million in total (Physicians for Social Responsibility, 2015). The "war on terror" is fueled by Islamophobia.

The aim of this article is to provide educators with the background information and pedagogical approaches needed to teach about Islamophobia and to help students develop critical media skills. In the first part of the article, I provide examples of Islamophobia and hate speech in the media and the internet before and after 9/11. These examples include how Muslims are "used", "othered", misrepresented, and painted as a homogenous group. In the last part of this article, I provide four pedagogical approaches that educators can consider when teaching critical media skills within this context.

\section{Background on the 'War on Terror' and Islamophobia}

Islamophobia has been described as a form of racism (which is not based on physical features but on religious orientation) as well as an unfounded fear of Islam (Marranci, 2004). It focusses on misrepresenting the Muslim world, highlighting differences in worldviews and presenting the Muslim as a lethal threat to western wealth and values. "Islamophobia is closed-minded prejudice against or hatred of Islam and Muslims" (Council on American-Islamic Relations (CAIR), 2013, p. 136). This prejudice takes the form of hate crimes and hate speech. For example, in 2011, the Federal Bureau of Investigations reported that there were 157 anti-Muslim hate crimes committed in the United States which is a substantial increase from 107 hate-crimes committed two years prior in 2009 (CAIR, 2013, p. 57).

According to Delgado and Stefancic (2014), hate speech is "a broader pattern of antisocial behaviour" (p. 320) which has found a home on the internet as the perpetrators can hide under an anonymous guise. They found that hate speech aimed at and about African Americans, Latinos, women, Jews, gays, and Muslims is on the rise in cyberspace. Unlike the impermanence of graffiti, hateful remarks on the internet are permanent, serve to erode public trust and weaken social bonds. "The way it works is that an idea is put forward, then again and again until it is believed without question. The Internet's dark side globally propels Dark Age beliefs to millions at the click of a mouse" (Baum in Delgado \& Stefancic, 2014, p. 329). It's like cursing at other drivers on the road. Would you do it if you knew they could hear you? The internet offers a forum for like-minded people to congregate and share their darker views knowing that they are invisible.

A report produced by the Council on American-Islamic Relations (CAIR) found that in 2012, there were 37 groups in the United States whose prime purpose is to spread the hate of Islam and Muslims and 32 groups who regularly demonstrate anti-Islamic themes in their literature. Common themes include: "Islam is not a religion," "Islam is a violent religion," "All Muslims are violent extremists" and "Muslims plan to subjugate America and supplant the constitution" (CAIR, 2013, p. 37). After analyzing anti-Muslim rhetoric, the Council found distinct strategies used to promote hate speech. Some of the strategies include: "Frame Muslim-Americans as 
dangerous to America", "twist statistics and fake research to prove the Muslim threat" and "defend liberty by taking away freedoms away from Muslims" (CAIR, 2013, p. 39). The latter strategy is demonstrated by the Council's findings that 78 bills were introduced into the legislatures of 29 states in 2012 which serve to vilify Islam. However, the most disturbing of the Council's findings is the growing trend for the public acceptance of the denigration of Islam (CAIR, 2013).

In 2011 American Councilwoman Deborah Pauly made a public statement outside a fundraising event for a Muslim charity in California. She told a crowd (which included children), "What's going on over there [at the fundraiser] right now ... that is pure, unadulterated evil," and "Make no mistake my friends, those who are assembling are enemies of America." Later she added, "I know quite a few Marines who will be very happy to help these terrorists to an early meeting in paradise" (CAIR, 2013, p. 76). When a public figure is not held responsible for hateful remarks, it opens the flood gates for the electorate to do the same. As another example, American conservative journalist Ann Coulter is quoted as saying, "Not all Muslims are terrorists, but all terrorists are Muslim" (cited by Elver, 2012, p. 145).

Bob Lovelace, a professor from Queen's University, was banned from Canadian Prime Minister Harper's Facebook page for voicing opposition to Harper's economic strategy. Lovelace questioned why the Prime Minister would ban him for exercising his democratic right yet allow the proliferation of hate speech on his Facebook page. Quotes on Harper's page included: "Muslims are having big families because that is their strategy to take over. The children are considered soldiers for Mohamad's (sic) army." "Keep middle eastern migrants out of our country. They are not compatible with us." "It's not a Canadian value to cover your face. It is a true insult for all true Canadians. Show some respect for the Great country that allowed you to live here. It is a privilege" (Lovelace, 2015). For a leader of a country to allow Islamophobia to be voiced on his social media site is a significant step to the normalization of "othering" Muslims. There are hundreds of denigrating remarks made by public figures about Islam and Muslims who have incurred no consequences. If the speaker had been referring to any other established religious group, "there would be consequences and public outcry" (Elver, 2012, p. 168).

Another means of misrepresenting the Muslim world is to paint all Muslims with the same brush. "Politicians and journalists in the West often feel sufficiently qualified to paint psychological portraits of millions of 'Orientals' as if they are a single, homogeneous mass (Saeed, 2007, p. 458). A good example of the grave consequence of this misconception is the Sikh Gurdwara killings in Wisconsin in 2012. This crime was the result of a white supremacist not knowing the difference between Sikhs and Muslims because in his mind, they are all the same (Afridi, 2013).

There is substantial diversity among Muslims which is evident by the findings from the 2011 survey conducted by the Pew Research Center. They surveyed 1,033 Muslims who live in the United States and found that Muslims in the United States originate from at least 77 countries and include native-born African Americans and other converts to Islam. The breakdown is as follows:

- $41 \%$ of Muslims come from the Middle East or North Africa. 
- $26 \%$ come from South Asian nations including Pakistan (14\%), Bangladesh (5\%) and India (3\%).

- $11 \%$ come from Sub-Saharan Africa, various countries in Europe (7\%), Iran (5\%), or other countries $(9 \%)$.

Painting Muslims from the Middle East, Africa and South Asia with the same brush has led to mass ignorance on the cultural diversity of those who practice Islam. "Arabs and Muslims have been racialized, essentialized, and lumped together as a homogeneous, dangerous group that is dramatically different from mainstream American society" (Elver, 2012, p. 152). Because there is no differentiation between the groups, hate speech and hate crimes target anyone who may practice Islam which has led to multiple hate crimes committed as a result of mistaken identity.

Shortly after 9/11, Mark Strohman began shooting people who he believed were responsible for $9 / 11$. He went into a store, asked the worker where he was from and shot him in the face. Strohman murdered two other people that day, one Muslim and one Hindu. "Strohman later testified that he was hunting Arabs, but none of the three men he killed were Arab" (CAIR, 2013, p. 45). These incidents unfortunately continue. In 2012, Erika Menendez pushed a person she had never met, Sunando Sen, a non-practicing Hindu, into a New York subway train. Sen was killed. Menendez told authorities, "I pushed a Muslim off the train tracks because I hate Hindus and Muslims. Ever since 2001 when they put down the Twin Towers, I've been beating them up" (CAIR, 2013, p. 57). The hate that motivated Menendez to take a life was a product of relentless reporting of $9 / 11$ by the media and the American government's disparaging stance. For three days, the networks showed images of the falling Twin Towers repeatedly,

... as if repetition were necessary to master a highly traumatic event. The

spectacle conveyed the message that the U.S. was vulnerable to terror

attack, that terrorists could create great harm and that anyone at anytime

could be subject to a violent terror attack, even in Fortress America.

(Kellner, 2004, pp. 3-4)

The mainstream media quickly likened the event to the "clash of civilizations" whereas Muslims were "evil" (used five times by Bush in his opening remarks about 9/11) and "uncivilized" and therefore a military intervention must ensue. Kellner (2004) argues that the nature of a democracy is its capacity to look at emerging issues with a critical lens. That lens was missing right after $9 / 11$ and was replaced by war fever created by the government and media. This was done by television and newspapers choosing to provide narrow views by conservative and right wing intellectuals underlining that this was a war against Islam and a war against good and evil.

\section{The Media's Contribution to Islamophobia}

This section examines how the media essentializes Muslims and provides examples of hate speech printed in mainstream media which promote racist ideas and "others" the Muslim community; unbalanced reporting; the use of blaming and how it is used to reinforce stereotypes. Finally, evidence is provided on how the media has used the "war on terror" or the war on Muslims to sell newspapers and how government bodies have used this position of the media to put forward their political agendas. 
Esposito, a scholar on Islam stated, "There is no lack of hate speech in the media and in print to empower Islamophobia. The media, whose primary incentive is sales and circulation, caters to explosive, headline events: 'What bleeds, leads"' (Esposito, 2010, p. 2). Esposito found multiple right wing and anti-Islam blogs which bash Muslims, Islam and those who support freedom of religion (Esposito \& Lalwani, 2011).

Media Matters for America (MMFA) gathered a number of statements made on Fox News about Muslims which were presented as facts. These include "all terrorists are Muslims;" "Every terrorist on American soil has been a Muslim;" "Muslims tend to be more violent than Christians;" "A high percentage of Muslims hate Jews and Christians" and according to Crowder "the real problem is the Quran" (MMFA, 2012). Hatred of this magnitude can cause great harm to our social fabric.

Networks such as CNN and Fox notoriously lead with stories about the fraction of deadly and dangerous acts committed by Muslims and ignore the achievements of millions of Muslims around the world who lead decent, law-abiding lives. There is a growing body of research that demonstrates the imbalance of images, and predominantly negative and hostile representations and discourses relating to Islam/Muslims in mainstream Western media. In fact, in recent years in the UK newspapers, the mention of "Muslims" increased over 250\% (Saeed, 2007).

In his research on Islamophobia, Elver (2012) provides evidence of how Arabs and Muslims are blamed for brutal acts and "othered" by American journalists. He provides the example of the journalist Steven Emerson, who publically, falsely ascribed the Oklahoma City bombing to Muslim terrorists. No apology was forthcoming for the error. The bomber, Timothy McVeigh, was then represented in the media as a "disturbed individual" for killing 900 people. The word "terrorist" was not attached to his act. Is it reserved only for Arabs and Muslims? Other examples include James Holmes' shooting rampage in Colorado at a movie theatre and Jared Loughner who killed six people in Tucson, Arizona. Both were labelled as mentally disturbed even though their attacks were premeditated. However, the "Boston Massacre" committed by two brothers from Chechnya, a country with a Muslim majority, was labelled as "terrorism". The suspects were immediately connected to a global network and the acts were categorized as global terrorism because the perpetrators were Muslim:

Terrorism has taken the position of perpetrator and victim. For example,

if a Muslim American woman were to be shot by a European American

male, it would be seen as domestic violence but had she shot him, it would be read as terrorism and the focus of the piece would reinforce the global threat of Islam to America (Afridi, 2013, p. 228).

When the attacks occurred in Norway in July 2011 the event was immediately reported as an act of Islamic terrorism. The Wall Street Journal and the New York Times attributed the act to an unknown terrorist group, "Ansar al-Jihad al-Alami." They revised the articles once they found out that no such group exists with that name. Later police arrested Anders Behring Breivik, a 32year-old Norwegian right-wing extremist who was a self-proclaimed Islamophobe. Shortly after 9/11, the Bush Administration was quoted as being committed to "smoke out and pursue... evil doers, those barbaric people. The semantically insensitive and dyslexic Bush administration also used cowboy metaphors, calling for bin Laden "dead or alive" (Kellner, 2004, p. 5). Bush 
repeatedly claimed that the war needed to be fought for American "freedom" which to Bush manifested in carte blanche to do whatever he deemed fit (Kellner, 2004). This included the extreme marginalization of those who practice Islam. Hall (1999) uses the example of how words such as "freedom" and "liberation" which used to mean the freeing of the oppressed but now the American government has appropriated these words and communicates them back in such a way that they are understood but the real meaning is not challenged. An example of this is "Operation Iraqi Freedom" which associates death and bombing with the cherished American value of "freedom". Hall (1999) argues that symbolic violence demonstrated by the Bush government fosters an extreme form of marginalization known as "exteriorization". Those who are exteriorized not only operate on the margins; their voice is incomprehensible to the dominant group as they are considered expendable.

Despite ample examples of prejudice, hate and racism, a survey conducted by the Pew Research Centre in 2011 found no evidence of an increase in feelings of alienation or anger among Muslim Americans. Furthermore, the survey found no evidence of an increase in rising support for Islamic extremism by Muslim-Americans. A significant number of Muslim Americans, 28\%, reported being looked at with suspicion; $22 \%$ revealed that they had been called offensive names; $21 \%$ reported being singled out by airport security, and $13 \%$ said they have been singled out by other law enforcement. The majority of respondents, $52 \%$, felt that their community is targeted unfairly in anti-terrorism policies and experience excessive surveillance and monitoring. Public opinion polls shortly after $9 / 11$ revealed that $60 \%$ of Americans were in favour of ethnic profiling of Arabs or Muslims (Elver, 2012). "Nonetheless, Muslim Americans have not become disillusioned with the country. They are overwhelmingly satisfied with the way things are going in their lives (82\%) and continue to rate their communities as very positive places to live (79\% excellent or good)" (Pew Research Centre, 2011, p. 3 ).

\section{Teaching about Terror and Hate}

"The quality of life in the new millennium will depend much more on the capacity of human beings to find ways to resist the draw of victimizing and brutalizing others, and the seduction of joining those who build their sense of identity and value on the indignity of others." (Shapiro, 2005, p. 64)

How can we as educators foster an understanding of Islamophobia, its history and the more subtle ways it manifests on the internet and in the media? How can we help students identify reports in the media that serve to encourage and institutionalize "Islamophobia"? What pedagogical approaches will lead students to stand up against this type of racism?

To help students analyze the role the media, the internet and governments play in fostering prejudice, racism and hate, students need to be taught how to think deeply and critically about the subject matter. The impact of hate needs to have a face and voice and be brought down to the level of their community and friends keeping in mind that for youth to take action for social change they need to feel a degree of hope that their actions will be fruitful. I propose the use of multiple pedagogical techniques to achieve these aims. The first is put forward by Newmann and 
Wehlage (2002) who have suggestions for educators on how to achieve higher order thinking. Second, the application of peace education is proposed to foster critical thinking. Third, I propose integrating the use of storytelling as a means to personify the suffering invoked by Islamophobia. Finally, the use of "hope education" as put forward by Shapiro (2002) is put forward as a means to spur students into social action.

\section{Higher Order Thinking}

Newmann and Wehlage (2002) argue that instruction should aim for "authentic achievement" which includes students using inquiry to construct knowledge leading to meaningful discourse. They argue that content presented to students should contribute to "connectedness" which means the students should be able to apply what they learned inside the classroom to various contexts outside the classroom. Similar to Bloom's (1994) taxonomy of educational objectives, Newmann and Wehlage (2002) make a distinction between lower level thinking (recitation/regurgitation of facts, repetitive routines and applying formula) and higher order thinking (manipulation of information which creates new meaning). For example, a lower level learning objectives would provide students with a checklist of inflammatory language and ask them to find examples in the media and the internet. Higher level learning objectives would include presenting a number of articles from the media and asking students to challenge what is claimed within each article and then to create a rebuttal.

\section{Critical Peace Education}

The foundation of an educational endeavour that aims to challenge racism and prepare its recipients to take action needs to be grounded in critical peace education. The objective of critical peace education is to challenge the status quo; provide an alternative vision of society; and to develop values, attitudes and skills that are aligned with those objectives (Bar-Tal, 2005). The focus is on social and political inequities and how participants can transform their communities and create social change (Bajaj, 2008). Objectives are concrete and relevant to the students and therefore methodologies lean towards experiential learning as this is the means to internalize new values, attitudes and skills. To challenge racism, educators need to provide counter narratives and create learning environments in which students can engage as critical readers who deconstruct the language of war and analyze the underlying messages.

Using a variety of editorials from newspapers that underline the assault of Arabs, Muslims and Middle Easterners on Western lifestyles, Gergen (in Lincoln et al., 2004) suggests asking students to examine the assumptions made by each author about the nature of aggression, patriotism, terrorism, and what motivates people in their actions. His purpose is to help students understand that there are other points of view beyond CNN. "It is an attempt to bring an interpretive perspective into the room where there seems to be little space for conversational differences" (p. 147). The next step would be for students to write an editorial to a newspaper challenging and debunking the assumptions made by that newspaper. 


\section{Integrating Storytelling}

Often peace education requires opposing groups to develop an understanding of each other (BarTal, 2005). Reconciliation and understanding start from empathy. Storytelling creates mutuality as it is inherently a shared activity. It creates connectivity between human beings and subsequently a space for empathy. When this empathy is created, it can prevent further abuse of the "other". Hearing stories from the other side challenges pre-conceived notions and forces the deconstruction of stereotypes. "In the process of listening to stories as they are told, a room full of strangers can become a room full of familiar and congenial people with amity (Jayakumar, 2015 , p. 4). Listeners can begin to experience the other side, that is, assailants inevitably get insights on how their victims may have felt. For those victims, storytelling has the power to heal.

Storytelling has the potential to transform social conflicts. In the process of telling their stories, storytellers can effect a change in how they are perceived from the outside. In effect, stories engage both the teller and the recipient in a collaborative process of making meaning and constructing values of empathy and tolerance while deconstructing myths, misconceptions, and stereotypes (Jayakumar, 2015).

Personal stories can be incorporated within lessons to combat Islamophobia. They would serve to give the "other" a face and a voice. Students could be asked to develop a list of what they believe to be true about Muslims. Muslim students could then be asked to share their stories about their families, beliefs and practices. Students could then re-visit their lists and identify the myths they have bought into and then begin to analyze the origins of their assumptions.

\section{Education for Hope}

Once students are able to think critically and deeply about the subtle ways Islamophobia manifests on the internet and in the media, they need to be encouraged to take social action. "In order to remake our world we must first be able to re-envision it-to dream that something different can exist in place of what we now have" (Shapiro, 2002, p. 7). That visioning is not possible without a sense of hope. This involves not only nurturing the emotional involvement of students in issues such as the inequity of power, social justice, and domination but also making room within the study of these challenging topics for imagination and creativity. The educator needs to instil hope to ensure students do not see institutionalized oppression as insurmountable or an inevitable part of life. Rather they should be inspired to be active agents of change (Shapiro, 2002). This inspiration can be found through the stories of others who have stood up as change agents. "Education needs to be understood as more than simply a mirror that reflects the existing culture; it may also represent a light that directs our way to a more hopeful future" (Shapiro, 2002, p. 7).

In the classroom, stories can be presented that demonstrate ordinary people standing up against Islamophobia, "People Are Forcing Islamophobic Bigots off Twitter" (Lee, 2015), "One Woman's Stand Against an Islamophobic Bus Passenger Deserves a Standing Ovation" (CheneyRice, 2015), and "Diverse and Strong Voices Emerging - 15,000 Stood up to Racism and 
Fascism in the UK" (Hassan, 2015). Stories such as these challenge students to stand up as these ordinary citizens have done.

\section{Conclusion}

Although according to the Pew Research Centre, it appears that Muslim-Americans are not overly impacted by Islamophobia, I would argue that there is something deeply wrong if a persecuted group begins to perceive the attack on their human rights as part of life. This rings of Bourdieu's symbolic violence where acts of violence begin to appear normal. Marginalizing can impact a group in insipid ways such as lower self-esteem; instil learned helplessness and a belief in one's own inferiority to the dominant group. Creative, bold educators are well-positioned to tackle Islamophobia in the classroom and plant seeds in the minds of youth so that they can envision a future without hate. 


\section{References}

Afridi, M. M. (2013). The Gurdwara Sikh killings: Domestic or global taxonomy of terrorism? Sikh Formations, 9(2), 227-233.

Bajaj, M. (2008). "Critical” peace education. In M. Bajaj (Ed.), Encyclopedia of peace education (pp. 135-146). Charlotte, North Carolina: Information Age Publishing Inc.

Barsamian, D. (2006, October). Gore Vidal Interview. The Progressive. Retrieved from http://www.progressive.org/mag_intv0806

Bar-Tal, D. (2005). The elusive nature of peace education. In B. Salomon, \& G. Nevo (Eds.). Peace education: The concept, principles, and practices around the world (pp. 27-36). Mahwah, New Jersey: Lawrence Erlbaum Associates.

Bloom, B. S. (1994). Reflections on the development and use of the taxonomy. Yearbook: National Society for the Study of Education, 9(2), 1-8.

Cheney-Rice, Z. (2015). One woman's stand against an Islamophobic bus passenger deserves a standing ovation. Mic, 1-11. Retrieved from http://mic.com/articles/115634/one-woman-sstand-against-an-islamophobic-bus-passenger-deserves-a-standing-ovation

Council on American-Islamic Relations. (2013). Legislating fear: Islamophopia and its impact in the United States. Retrieved from http://www.cair.com/images/islamophobia/LegislatingFear.pdf

Dean, J. (2008). Communicative capitalism: Circulation and foreclosure of politics. In M. Boler (Ed.). Digital media and democracy: Tactics in hard times. MIT Press. Retrieved from http://citeseerx.ist.psu.edu/viewdoc/download?doi=10.1.1.474.9002\&rep=rep1\&type=pdf\#p age $=112$

Delgado, R., \& Stefancic, J. (2014). Hate speech in cyberspace. Wake Forest Law Review, 49(2), 319-344.

Elver, H. (2012). Racializing Islam before and after 9/11: From melting pot to Islamophobia. Transnational Law and Contemporary Problems, 21(119), 119-174.

Esposito, J. L ., \& Lalwani, S. B. (2011, May 25). Bigotry and Islam: Bill O’ Reilly's at it again. Huffington Post. Retrieved from http://www.huffingtonpost.com/john-l-esposito/bigotryand-islam-bill-or_b_765300.html

Esposito, J. L. (2010, November 8). Islamophobia: A threat to American values? Huffington Post. Retrieved from http://www.huffingtonpost.com/john-1-esposito/islamophobia-a-threatto_b_676765.html

Evans, J. (2012). Politics, stereotypes and terrorism: The politics of fear in liberal democracies. The International Journal of Interdisciplinary Social Sciences, 6(5), 71-80.

Gershkoff, A., \& Kushner, S. (2005). Shaping public opinion: The 9/11-Iraq connection in the Bush administration's rhetoric. Perspectives on Politics, 3(3), 525-537.

Hall, J. M. (1999). Marginalization revisited: Critical, postmodern, and liberation perspectives. ANS. Advances in Nursing Science, 22(1), 88-102.

Hassan, A. (2015). Diverse and strong voices emerging - 15,000 stood up to racism and fascism in the UK. Muslim Association of Britain. Retrieved from http://www.mabonline.net/diverse-and-strong-voices-emerging-15000-stood-up-to-racismand-fascism-in-the-uk/

Jayakumar, K. (2015, May 14). Storytelling for peace. Insight on Conflict. Retrieved from http://www.insightonconflict.org/2015/05/storytelling-peace/ 
Kellner, D. (2004). 9/11, Spectacles of terror, and media manipulation: A critique of Jihadist and Bush media politics. Critical Discourse Studies, 1(1), 41-64. http://dx.doi.org/10.1080/17405900410001674515

Lee, A. (2015). People are forcing Islamophobic bigots off Twitter. Buzzfeed. Retrieved from http://www.buzzfeed.com/alexlee/i-stand-with-mariam\#.fcaZ17x1pZ

Lincoln, Y., Weems, M., Denzin, N., Fine, M., Hughes, R., Weis, L., ... \& Gergen, M. (2004). Performing 9/11: Teaching in a terrorized world. Qualitative Inquiry, 10, 140-159. http://dx.doi.org/10.1177/1077800403255773

Lovelace, R. (2015). No place in Canada for bigots. Youtube. Retrieved from https://www.youtube.com/watch?v=D8TBPfN8968

Marranci, G. (2004). Multiculturalism, Islam and the clash of civilisations theory: rethinking Islamophobia. Culture and Religion, 5(1), 105-117. http://dx.doi.org/10.1080/0143830042000200373

Media Matters for America. (2012, June 18). Fox news contributor : "A high percentage" of Muslims "hate Christians and Jews"; The real problem is the Quran. Retrieved from http://www.mediamatters.org/blog/2012/06/28/fox-news-contributor-a-high-percentage-ofmusli/184244

Newmann, F. M., \& Wehlage, G. G. (2002). Five standards of authentic education. Educational Leadership, 50(7), 8-12.

Pew Research Centre. (2011). Muslim Americans: No signs of growth in alienation or support for extremism. Retrieved from http://www.people-press.org/2011/08/30/muslim-americansno-signs-of-growth-in-alienation-or-support-for-extremism/

Physicians for Social Responsibility. (2015). Body count: Causualty figures after 10 years of the “War on Terror. ” Retrieved from http://www.psr.org/assets/pdfs/body-count.pdf

Saeed, A. (2007). Media, racism and Islamophobia: The representation of Islam and Muslims in the media. Sociology Compass, 2(1), 443-462. http://dx.doi.org/10.1111/j.17519020.2007.00039.x

Shapiro, S. (2002). Lessons of September 11. Tikkun, 17(4), 13.

Shapiro, S. (2005). Critical pedagogy of peace education. In G. Salomon, \& B. Nevo (Eds.). Peace education: The concept, principles, and practices around the world (pp. 63-73). Psychology Press. 